\title{
Stable isotope and minor element proxies for Eocene climate of Seymour Island, Antarctica
}

\author{
Andrea L. Dutton and Kyger C Lohmann \\ Department of Geological Sciences, University of Michigan, Ann Arbor, Michigan, USA
}

\section{William J. Zinsmeister}

Department of Earth and Atmospheric Sciences, Purdue University, West Lafayette, Indiana, USA

Received 22 September 2000; revised 2 July 2001; accepted 18 September 2001; published 10 May 2002.

[1] Abundant and well-preserved marine macrofossils on Seymour Island, Antarctica, provide a valuable resource to establish paleoenvironmental conditions at high southern latitudes during the warm Paleogene. Stable isotope, minor element, and ${ }^{87} \mathrm{Sr}{ }^{86} \mathrm{Sr}$ compositions have been measured for the aragonite bivalve Cucullaea from the Eocene La Meseta Formation. The ${ }^{87} \mathrm{Sr} /{ }^{86} \mathrm{Sr}$ stratigraphy suggests an early to late Eocene age for the La Meseta Formation. Sea surface temperature estimates based on $\delta^{18} \mathrm{O}$ values range from $14.5^{\circ}$ to $15.5^{\circ} \mathrm{C}$ in the early and middle Eocene to $10.5^{\circ} \mathrm{C}$ in the late Eocene. High-resolution sampling along growth structures provides estimates of seasonality in temperature, which decrease considerably up section. To address the relative contribution of temperature and ice volume or salinity to the $\delta^{18} \mathrm{O}$ record, $\mathrm{Sr} / \mathrm{Ca}$ was measured and evaluated as a potential independent paleothermometer for CUcullaea. INDEX TERMS: 4215 Oceanography: General: Climate and interannual variability (3309); 4267 Oceanography: General: Paleoceanography; 4870 Oceanography: Biological and Chemical: Stable isotopes; 9310 Information Related to Geographic Region: Antarctica KEYWORDS: bivalve, oxygen isotope, seasonality, paleotemperature, Cucullaea

\section{Introduction}

[2] A wealth of evidence derived from of oceanographic and terrestrial records indicates that the early Eocene was characterized by an unusually warm global climate [Greenwood and Wing, 1995; Zachos et al., 2001]. Foraminiferal $\delta^{18} \mathrm{O}$ data indicate significantly reduced latitudinal temperature gradients in the oceans during this time [Zachos et al., 1992]. Global early Eocene warmth deteriorated during middle and late Eocene along a gradual cooling trend that lasted roughly 17 million years [Zachos et al., 2001]. Enough cooling had occurred by earliest Oligocene to allow for the development of a major ice sheet in Antarctica [Mackensen and Ehrmann, 1992].

[3] Several recent estimates of climate parameters during the early Paleogene have been based on studies of molluscan $\delta^{18} \mathrm{O}$ [Bice et al., 1996; Andreasson and Schmitz, 1996, 1998, 2000; Purton and Braiser, 1997; Purton et al., 1999; Schmitz and Andreasson, 2001]. Analysis of molluscan carbonate provides information for small windows of time, yet these measurements offer valuable insights into paleoclimate that serve as benchmarks for models of ancient climate and ocean circulation. One notable advantage of molluscan records versus foraminiferal-based records is the preservation of seasonal variability in $\delta^{18} \mathrm{O}$ within accretionary growth structures.

[4] Unfortunately, fossil records in polar regions are limited, due in part to poor fossil preservation and extensive ice cover. Neritic marine deposits exposed on Seymour Island situated adjacent to the Antarctic Peninsula are remarkable for the excellent preservation of Cretaceous and Paleogene floras and faunas that have been the subject of numerous paleontological studies [e.g., Woodburne and Zinsmeister, 1984; Zinsmeister, 1984; Zinsmeister and Feldmann, 1984; Wrenn and Hart, 1988; Case, 1992; Doktor et al., 1996; Aronson et al., 1997]. Molluscan faunas such as those

Copyright 2002 by the American Geophysical Union. 0883-8305/02/2000PA000593 preserved on the Seymour Island provide a rare opportunity to collect oxygen isotope data from a high-latitude coastal environment for multiple time slices during the Eocene.

[5] This investigation provides a record of the evolution of sea surface temperatures and seasonal temperature variation along coastal Antarctica during the transition from early Eocene warmth to early Oligocene glaciation using stable isotope data derived from the aragonite bivalve, Cucullaea. The motivation for this study is twofold. First, we seek to provide a record of paleoclimate that can be integrated with evolutionary and ecological observations of the La Meseta fauna. Second, our reconstruction of sea surface temperature (SST) and amplitude of temperature variation can be combined with data from lower-latitude sites to provide a pole-toequator temperature gradient. Ultimately, these data can be compared with paleoclimate models and add to our understanding of the dynamics of ancient polar climates.

\subsection{Geologic Setting}

[6] Seymour Island is a small, ice-free island located $\sim 100 \mathrm{~km}$ east of the Antarctic Peninsula at $64^{\circ} 17^{\prime} \mathrm{S}, 56^{\circ} 45^{\prime} \mathrm{W}$; it has remained at the same latitudinal position since the mid-Cretaceous [Norton and Sclater, 1979] (Figure 1). Deposits exposed on Seymour Island developed in response to uplift and erosion of the northern Antarctic Peninsula during subduction along the western margin of the peninsula [Elliot, 1988]. The La Meseta Formation, as established by Elliot and Trautman [1982], crops out on the northeastern portion of Seymour Island around a small, topographically prominent mesa.

[7] The La Meseta Formation is a richly fossiliferous, shallow marine succession consisting of $\sim 700 \mathrm{~m}$ of intercalated conglomerates, sandstones, and shell banks as well as unconsolidated sediment [Elliot and Trautman, 1982]. It has been subdivided by Sadler [1988] into seven separate mappable units separated by unconformities, designated from oldest to youngest as Tertiary Eocene La Meseta (Telms) 1-7. A variety of near-shore environments have been inferred for these deposits including incised valley estuarine [Sadler, 1988; Porębski, 1995] and pro-delta to 


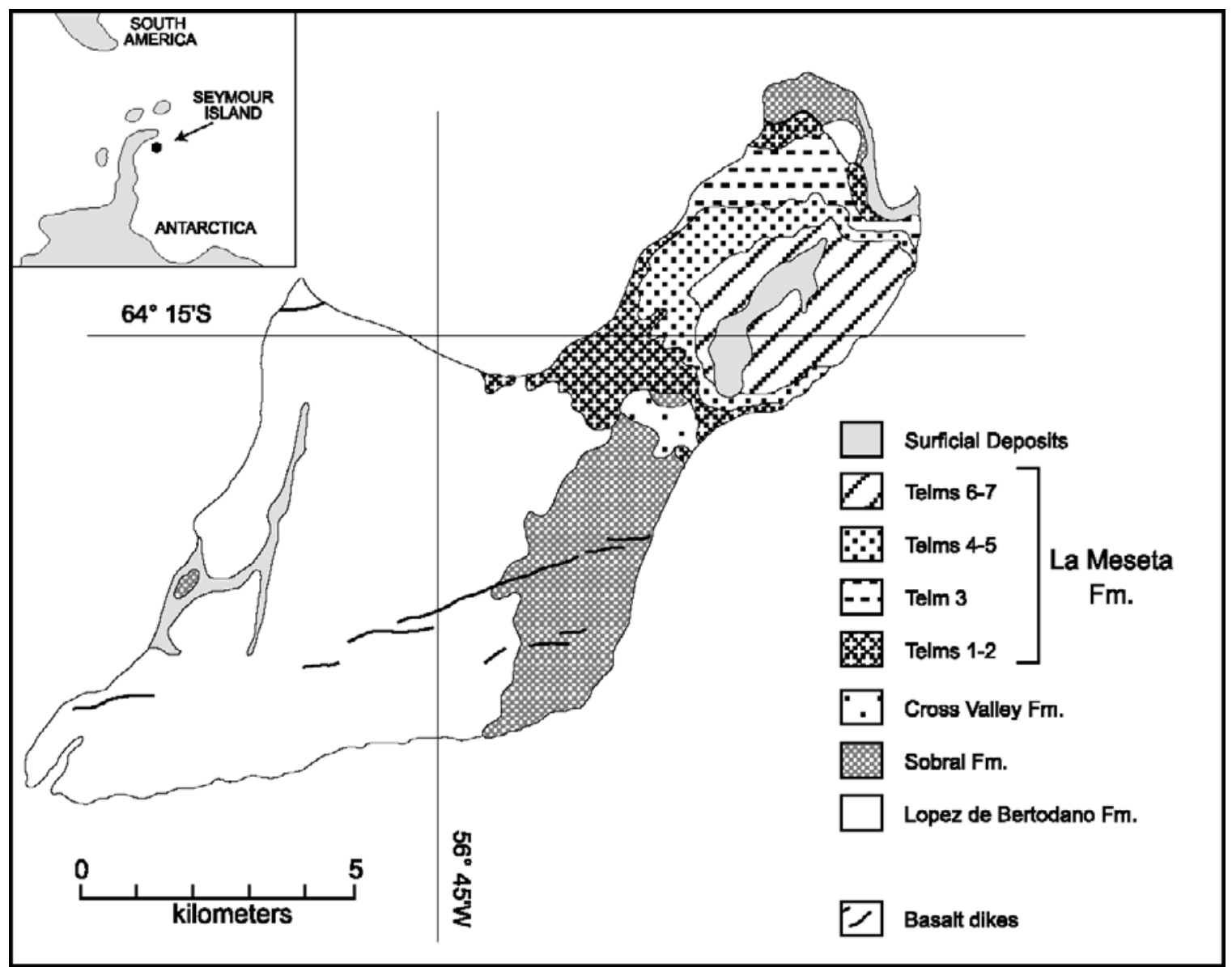

Figure 1. Geologic map of Seymour Island, Antarctica. The La Meseta Formation crops out on the northern portion of the island and is divided into seven mappable units, called Telms (Tertiary Eocene La Meseta).

lagoonal [Elliot and Trautman, 1982; Wrenn and Hart, 1988]. Sedimentological features suggest that the La Meseta Formation was tidally dominated and represents a highly lenticular, transgressive-regressive package of sediment [Porębski, 1995].

[8] Although detailed analyses of sedimentary features suggest that La Meseta lithofacies accumulated in an incised valley estuary [Sadler, 1988; Porębski, 1995], there is little faunal evidence for the presence of brackish water. Taxa represented in the La Meseta fauna include bivalves, gastropods, brachiopods, arthropods, fish, sharks, and whales [Wiman, 1905; Welton and Zinsmeister, 1980; Feldmann and Wilson, 1988; Weidman et al., 1988; Stilwell and Zinsmeister, 1992; Doktor et al., 1996] as well as a number of typically stenohaline taxa such as echinoids, asteroids, ophiuroids, crinoids, and corals [Blake and Zinsmeister, 1988; McKinney et al., 1988; Filkhorn, 1994; Baumiller and Gaździcki, 1996; Aronson et al., 1997]. These stenohaline taxa have physiological intolerances to lower salinities and are found to range across the entire formation; their presence therefore contributes strong evidence for normal marine salinities (i.e., $33-35 \mathrm{ppt})$.

\subsection{Age of La Meseta Formation}

[9] The precise age of the La Meseta Formation has been a subject of considerable debate [Woodburne and Zinsmeister, 1984, and references therein]. Difficulty in assigning an age to this deposit stems in part from the presence of floras and faunas endemic to Antarctica, which cannot be reliably placed into a global biostratigraphic context. Further complications arise from heterochroneity of the La Meseta fauna; 11 marine invertebrate genera previously known only from the late Cenozoic in middle and low latitudes have been discovered in the La Meseta Formation [Zinsmeister and Feldmann, 1984].

[10] Molluscan faunas [Zinsmeister and Camacho, 1982], microfloras [Wrenn and Hart, 1988; Askin et al., 1991], marsupials [Woodburne and Zinsmeister, 1984], shark teeth [Welton and Zinsmeister, 1980], and whales [Wiman, 1905] show strong affinities to Eocene assemblages. In particular, analysis of dinoflagellate floras indicates a late early Eocene to late Eocene age [Wrenn and Hart, 1988; Askin et al., 1991]. However, some La Meseta taxa are purported to be as young as early Oligocene [Hall, 1977; Welton and Zinsmeister, 1980]. Ambiguity has therefore persisted between a late Eocene or early Oligocene age assignment for the uppermost strata. The ${ }^{87} \mathrm{Sr} /{ }^{86} \mathrm{Sr}$ data presented here clearly indicate an age no older than late Eocene for Telm 7 of the La Meseta Formation.

\section{Methods and Results}

\subsection{Sampling Strategy}

[11] Geochemical analyses were restricted to the bivalve genus Cucullaea to facilitate comparisons within and among stratigraphic horizons. Cucullaea is a shallow, infaunal filter feeder and was chosen for study because of its robust shell and abundance throughout the section. The two species of Cucullaea in the La Meseta Formation (C. raea and C. donaldi) do not co-occur at any 


\section{Temperature ( $\left.{ }^{\circ} \mathrm{C}\right)$}

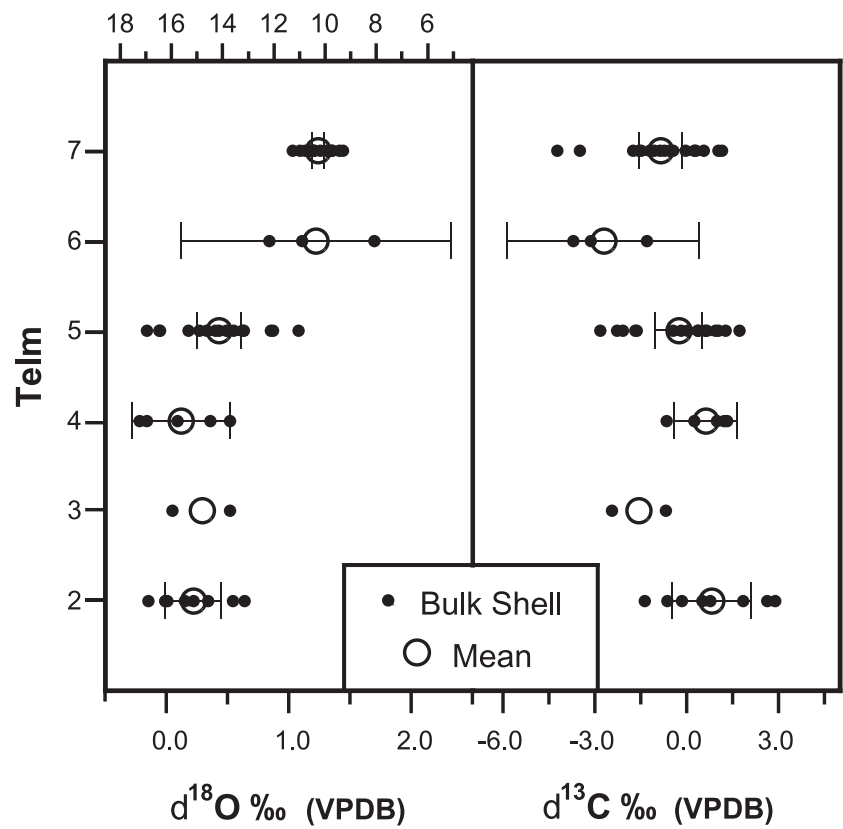

Figure 2. (left) Bulk shell $\delta^{18} \mathrm{O}$ and (right) $\delta^{13} \mathrm{C}$ of 52 Cucullaea specimens from the La Meseta Formation. Individual shell values (solid circles) are plotted for each stratigraphic horizon with mean values (open circles) for Telms $2-7$. The $95 \%$ confidence intervals are plotted as brackets; the large confidence interval for Telm 6 is due to a very small sample size $(n=3)$. Mean $\delta^{18} \mathrm{O}$ values do not vary significantly for Telms $2-5$ but increase by $0.8 \%$ in Telms 6 and 7.

stratigraphic level. C. raea is present in Telms $1-5$, whereas C. donaldi occurs in Telms 6 and 7. Specimens selected for analysis represent all Cucullaea-bearing localities in Telms 2-7 of the La Meseta Formation that are represented in the collection of W. Zinsmeister. The number of shells analyzed per Telm was limited in some cases because of the number of available specimens. Unfortunately, different localities within a Telm were not collected in measured sections, and therefore relative stratigraphic positions cannot be determined within each Telm.

[12] Two sampling techniques were implemented during this study. One was designed to provide a long-term record across stratigraphic horizons; the other was designed to provide subannual-scale records within each horizon. In the first case, bulk samples of carbonate were obtained by drilling across several years of growth near the umbo of the shell to obtain an average composition. This region of the shell is generally thicker and represents the early stages of shell accretion, so problems related to seasonal growth cessations associated with reproductive activities are minimized. A total of 52 bivalves (representing 28 sampling localities) were analyzed for bulk stable isotope composition.

[13] In the second case, high-resolution sampling was performed by digitizing a thick section of shell cut along the axis of maximum growth and interpolating drill paths between successive growth bands to produce a continuous time series of data. A computerized $X-Y-Z$ stage was used to mill out the interpolated paths as described by Dettman and Lohmann [1995]. All high-resolution samples were drilled from the outer, prismatic layer near the ventral margin (i.e., shell accreted late in the life span of the organism). Although shell growth may be interrupted during spawning intervals when the bivalve is older, this portion of the shell was chosen because the outer, prismatic layer is thickest toward the ventral margin, allowing for higher sampling resolution. Six bivalves representing Telms $2,4,5$, and 7 were sampled in this manner. We chose to sample three shells from Telm 5 (versus one specimen for each of the other Telms) because Telm 5 is the thickest and likely represents a greater span of time. Owing to shell fragmentation and abrasion, we were unable to generate high-resolution records for shells from Telms 3 and 6.

\subsection{Preservation of Specimens}

[14] X-ray diffraction analyses determined that the bivalve shells consist entirely of aragonite. In addition, all shells that were thick sectioned for high-resolution geochemical sampling were also examined petrographically and under cathodoluminescence. Shell microstructures are well preserved, and calcite cement is only visible growing out from the edge of the shell in a few specimens. Sediments of the La Meseta Formation readily luminesce, yet all bivalve shells were found to be nonluminescent. On rare occasions, luminescent fractures were found to cut across shells; these areas were avoided during high-resolution sampling.

[15] Slight alteration was detected in some samples demonstrating elevated minor and trace element composition (Mn > 300 ppm, Fe $>150 \mathrm{ppm}$ ); these samples are not included in the tabulated results. Fossil shells derived from Telm 1 of the La Meseta Formation exhibit iron oxide staining and pitting due to dissolution. These specimens appeared to be extensively altered under visual examination and were excluded from all geochemical analyses. Therefore only results for specimens from Telms 2 through 7 are reported here. ${ }^{1}$

\subsection{Stable Isotope Analyses}

[16] Roughly equal size splits of the carbonate powder $(\sim 20 \mu \mathrm{g}$ each) were taken for stable isotope and elemental analyses. Samples for stable isotope analysis were roasted in a vacuum at $200^{\circ} \mathrm{C}$ for 1 hour to remove volatile contaminants. Powder samples were individually reacted with anhydrous phosphoric acid at $72^{\circ} \mathrm{C}$ in an automated Kiel device which is directly coupled to a Finnigan MAT 251 isotope-ratio mass spectrometer. Precision of the data was maintained at better than $0.1 \%$ by daily analysis of powdered carbonate standards. All stable isotope compositions are reported in standard $\delta$ notation relative to the Vienna Peedee belemnite (VPDB) standard.

[17] The $\delta^{18} \mathrm{O}$ of bivalve aragonite ranges from -0.2 to $+1.7 \%$ across the entire formation (Figure 2). The observed trend in $\delta^{18} \mathrm{O}$ is characterized by low values in Telms 2 through 5 , followed by a shift to higher values in Telms 6 and 7 (Table 1). Average values of $\delta^{18} \mathrm{O}$ for Telms 2 through 5 are statistically indistinguishable at the $95 \%$ confidence interval. The $\delta^{13} \mathrm{C}$ values range from -3.6 to $+2.9 \%$ and tend to show more variation both within and between adjacent Telms than the $\delta^{18} \mathrm{O}$ data (Figure 2).

[18] Temperatures have been calculated from $\delta^{18} \mathrm{O}$ values using the empirically determined paleotemperature equation for aragonite molluscs of Grossman and $K u$ [1986]. A value for the oxygen isotope composition of seawater $\left(\delta^{18} \mathrm{O}_{\mathrm{SW}}\right)$ must be specified to calculate SST. The $\delta^{18} \mathrm{O}_{\mathrm{SW}}$ is influenced by several factors, including continental ice volume, continental runoff, precipitation and evaporation, and ocean circulation. We use a value of $-1.0 \%$ (SMOW) for the $\delta^{18} \mathrm{O}$ of global mean seawater for an ice-free world, according to the widely accepted estimate of Shackleton and Kennett [1975]. All temperatures are calculated assuming a constant, normal marine salinity during deposition of the La Meseta

\footnotetext{
${ }^{1}$ Supporting data are available electronically at World Data Center-A for Paleoclimatology, NOAA/NGDC, 325 Broadway, Boulder, CO 80303, USA (e-mail: paleo@mail.ngdc.noaa.gov; URL: http://www.ngdc.noaa. gov/paleo/data.html).
} 
Table 1. Results for Bulk Samples of Cucullaea ${ }^{\mathrm{a}}$

\begin{tabular}{ccccc}
\hline Telm & $\begin{array}{c}\text { Sample } \\
\text { Size }\end{array}$ & $\begin{array}{c}\delta^{18} \mathrm{O} \\
\text { (Average, } \\
\text { SD) }\end{array}$ & $\begin{array}{c}\delta^{13} \mathrm{C} \\
\text { (Average, } \\
\text { SD) }\end{array}$ & $\begin{array}{c}\text { Average } \\
\text { Temperature, } \\
{ }^{\circ} \mathrm{C}\end{array}$ \\
\hline 7 & 18 & $1.3,0.1$ & $-0.9,1.4$ & 10.5 \\
6 & 3 & $1.3,0.4$ & $-2.7,1.3$ & 10.5 \\
5 & 16 & $0.5,0.4$ & $-0.3,1.4$ & 14.5 \\
4 & 5 & $0.1,0.3$ & $0.6,0.8$ & 15.5 \\
3 & 2 & 0.3 & -1.6 & 15.0 \\
2 & 8 & $0.2,0.3$ & $0.8,1.2$ & 15.0 \\
\hline
\end{tabular}

${ }^{\mathrm{a}}$ Stable isotope measurements are reported in per mil with respect to the VPDB standard. Standard deviations are reported for Telms with $n>2$. Temperatures are calculated using the paleotemperature equation for aragonite molluscs [Grossman and $K u, 1986$ ], assuming constant salinity and an ice-free world $\left(\delta^{18} \mathrm{O}_{\mathrm{SW}}=-1.0 \%\right)$.

Formation unless otherwise indicated. Zachos et al. [1994] proposed that heterogeneities in surface $\delta^{18} \mathrm{O}_{\mathrm{SW}}$ arising from surface salinity gradients in the open ocean [Broecker, 1989; Fairbanks et al., 1992] can be corrected by invoking an equation relating modern surface $\delta^{18} \mathrm{O}_{\mathrm{SW}}$ and latitude. Yet the appropriateness of applying the modern $\delta^{18} \mathrm{O}_{\mathrm{SW}}$-latitude relation to ancient climates has been debated [Huber et al., 1995; Price et al., 1996]. In fact, simulations of surface ocean salinity during the Eocene suggest that processes controlling salinity gradients in the ocean may have been quite different [Bice et al., 1997]. Consequently, we chose not to adjust our $\delta^{18} \mathrm{O}$ data to account for possible latitudinal hetero- geneities in surface $\delta^{18} \mathrm{O}_{\mathrm{SW}}$. Note that applying this correction at the paleolatitude of Seymour Island would decrease $\delta^{18} \mathrm{O}$ values by $0.5 \%$, corresponding to a $2.4^{\circ} \mathrm{C}$ decrease in temperature relative to the unadjusted paleotemperatures reported herein. Working under these assumptions, average temperatures are $14.5^{\circ}-15.5^{\circ} \mathrm{C}$ in Telms $2-5$ and decrease markedly to $10.5^{\circ} \mathrm{C}$ in Telms 6 and 7 (Table 1). The total range of bulk $\delta^{18} \mathrm{O}$ values across the La Meseta Formation corresponds to a temperature span of $\sim 9.0^{\circ} \mathrm{C}$.

[19] High-resolution analyses were generated to assess variability in $\delta^{18} \mathrm{O}$ and $\delta^{13} \mathrm{C}$ on a subannual timescale (Figure 3 ). The series of data from each shell exhibit fluctuation in both $\delta^{18} \mathrm{O}$ and $\delta^{13} \mathrm{C}$ (Table 2). Growth bands do not show a consistent pattern in relation to seasonal $\delta^{18} \mathrm{O}$ maxima and minima, but $\delta^{13} \mathrm{C}$ maxima often coincide with growth bands. The range in $\delta^{18} \mathrm{O}$ values is greatest in Telm 5 (shell 453) and smallest in Telm 7 (shell 6). If all variability in the $\delta^{18} \mathrm{O}$ signal is a result of seasonal fluctuation in temperature, corresponding estimates of temperature seasonality range from $2.5^{\circ}$ to $11.5^{\circ} \mathrm{C}$. Alternatively, variability in $\delta^{18} \mathrm{O}$ on an annual timescale could be produced by seasonal runoff. Amplitude of seasonal variation in $\delta^{13} \mathrm{C}$ ranges from 1.3 to $1.9 \%$.

\subsection{Major and Minor Element Analyses}

[20] Major and minor elemental analyses were carried out with a Finnigan MAT inductively coupled plasma mass spectrometer (ICP-MS). Samples were dissolved in $1 \% \mathrm{HNO}_{3}$ and analyzed for $\mathrm{Ca}, \mathrm{Sr}, \mathrm{Mg}, \mathrm{Fe}$, and $\mathrm{Mn}$. Precision of the analyses was better than $3 \%$.

[21] Both $\mathrm{Mg} / \mathrm{Ca}$ and $\mathrm{Sr} / \mathrm{Ca}$ ratios were measured to investigate the relation between these minor element ratios and stable isotope
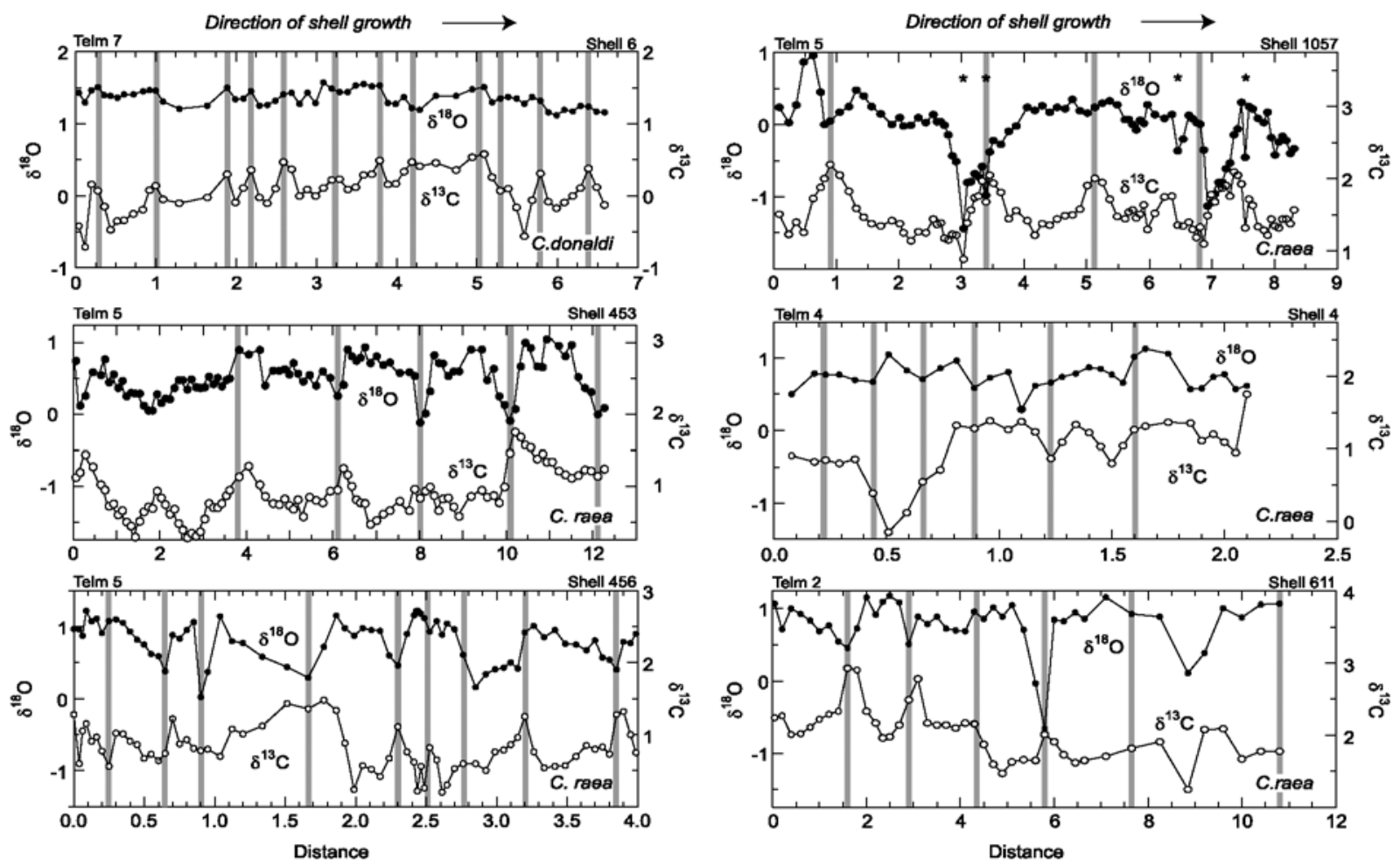

Figure 3. Profiles of $\delta^{18} \mathrm{O}$ (left scale, solid circles) and $\delta^{13} \mathrm{C}$ (right scale, open circles) plotted for six Cucullaea bivalves from the La Meseta Formation. Shaded lines denote location of dark growth bands in each shell; asterisks denote synchronous negative excursions in $\delta^{18} \mathrm{O}$ and $\delta^{13} \mathrm{C}$ for shell 1057 . Note the different $x$ axis scales for each shell; all $y$ axes are plotted on the same scale. Growth bands do not show a consistent pattern in relation to seasonal $\delta^{18} \mathrm{O}$ maxima and minima; $\delta^{13} \mathrm{C}$ maxima often coincide with growth bands. Shell 6 (Telm 7) shows the least seasonal variation in $\delta^{18} \mathrm{O}$. 
Table 2. Results for High-Resolution Samples of Cucullaea ${ }^{\text {a }}$

\begin{tabular}{ccccccccc}
\hline Telm & Clam & $\delta{ }^{13} \mathrm{C}$ Range & $\delta{ }^{18} \mathrm{O}_{\min }$ & $\delta{ }^{18} \mathrm{O}_{\max }$ & $\delta{ }^{18} \mathrm{O}$ Range & $T_{\min },{ }^{\circ} \mathrm{C}$ & $T_{\max },{ }^{\circ} \mathrm{C}$ & $T$ Range, ${ }^{\circ} \mathrm{C}$ \\
\hline 7 & 6 & 1.3 & 1.1 & 1.6 & 0.5 & 8.6 & 10.9 & 2.5 \\
5 & 1057 & 1.3 & -1.4 & 1.0 & 2.4 & 11.4 & 22.9 & 11.5 \\
5 & 456 & 1.3 & 0.0 & 1.2 & 1.2 & 10.5 & 16.2 & 5.7 \\
5 & 453 & 1.5 & -0.1 & 1.0 & 1.1 & 11.4 & 16.7 & 5.3 \\
4 & $4 \mathrm{~A}$ & 1.9 & 0.3 & 1.1 & 0.8 & 10.9 & 14.8 & 4.0 \\
2 & 611 & 1.5 & -0.7 & 1.2 & 1.9 & 10.5 & 19.6 & 9.1 \\
\hline
\end{tabular}

${ }^{\mathrm{a}}$ Isotope measurements are reported in per mil with respect to the VPDB standard. Temperatures are calculated using the paleotemperature equation for aragonite molluscs [Grossman and $K u, 1986]$ assuming constant salinity and an ice-free world $\left(\delta^{18} \mathrm{O}_{\mathrm{SW}}=-1.0 \%\right)$.

composition. Bulk samples obtained from three specimens from each stratigraphic horizon were analyzed for elemental composition. No correlation was observed for $\mathrm{Mg} / \mathrm{Ca}$ and $\delta^{18} \mathrm{O}$; a weak but statistically significant correlation $(p<0.001)$ was found between $\mathrm{Sr} / \mathrm{Ca}$ ratios and $\delta^{18} \mathrm{O}$ for both a linear and an exponential fit:

$$
\begin{array}{cc}
\mathrm{Sr} / \mathrm{Ca}=-5.1 \delta^{18} \mathrm{O}+13.3 & \left(r^{2}=0.59, n=16\right) \\
\mathrm{Sr} / \mathrm{Ca}=14.1 e^{\left(-0.61 \delta^{18} \mathrm{O}\right)} \quad\left(r^{2}=0.64, n=16\right) .
\end{array}
$$

[22] Elemental composition was also determined for highresolution samples from a single bivalve (shell 453, Telm 5) (Figure 4). No correlation was observed between $\mathrm{Sr} / \mathrm{Ca}$ and $\delta^{18} \mathrm{O}$ $\left(r^{2}=0.11\right)$ in this shell; however, a weak correlation between
$\mathrm{Sr} / \mathrm{Ca}$ and $\delta^{13} \mathrm{C}\left(r^{2}=0.45\right)$ was found to be statistically significant $(p<0.001)$.

\subsection{Strontium Isotope Analyses}

[23] Powdered samples of bivalve aragonite were dissolved in nitric acid, and strontium was subsequently separated using ion exchange chromatography with Eichrom Sr-specific resin. The effluent was dried and loaded onto a tungsten filament for isotope ratio analysis using a Finnigan-MAT 262 thermal ionization mass spectrometer. The ${ }^{86} \mathrm{Sr} /{ }^{88} \mathrm{Sr}$ ratio was normalized to 0.1194 , and measured ${ }^{87} \mathrm{Sr} /{ }^{86} \mathrm{Sr}$ ratios were corrected using the long-term laboratory average of NIST 987, $0.710259 \pm 0.000022(2 \sigma)$. Data reported herein have been adjusted to a NIST 987 value of 0.710248 in order to make numeric age assignments using the LOWESS curve fit following the method outlined by Howarth and McArthur [1997] (Table 3). Analytical uncertainty was calculated

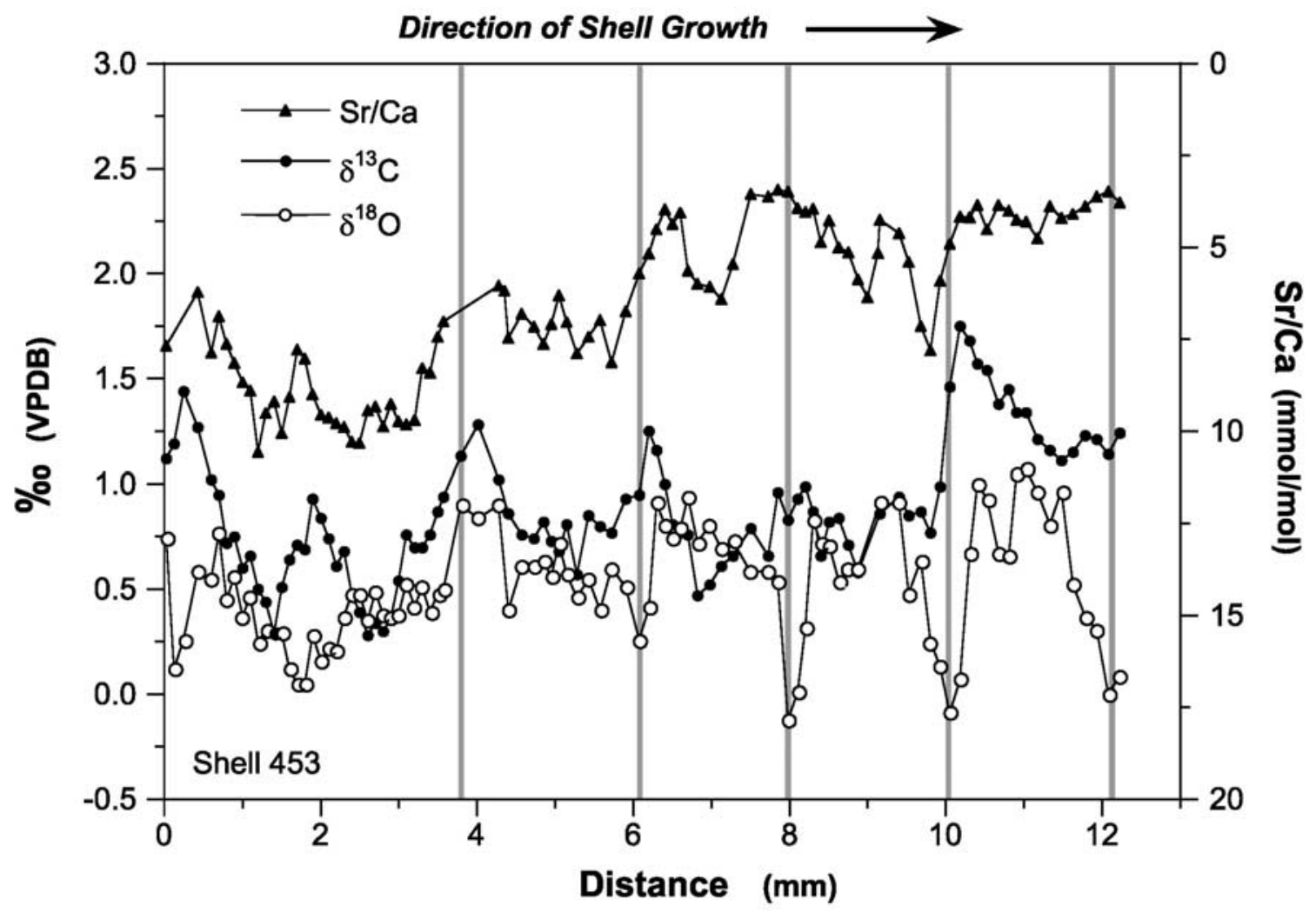

Figure 4. High-resolution profiles of $\delta^{18} \mathrm{O}, \delta^{13} \mathrm{C}$, and $\mathrm{Sr} / \mathrm{Ca}$ from Cucullaea raea shell 453, Telm 5 of the La Meseta Formation to assess degree of correlation between these variables. Shaded lines denote location of visible growth bands. Variation in $\mathrm{Sr} / \mathrm{Ca}$ shows no consistent relation to either $\delta^{18} \mathrm{O}$ or $\delta^{13} \mathrm{C}$ in this shell. 
Table 3. Sr Isotope Results for Bulk Samples of Cucullaea ${ }^{\text {a }}$

\begin{tabular}{cccc}
\hline Telm & Shell & ${ }^{87} \mathrm{Sr} /{ }^{86} \mathrm{Sr}$ & Age, Ma \\
\hline 7 & $1099-\mathrm{B} 2$ & 0.707784 & 34.69 \\
7 & $6-6-2$ & 0.707770, & 34.96 \\
& & 0.707788 & 36.13 \\
7 & $1055 \mathrm{~B}$ & 0.707761 & $>44.54$ and $<47.35$ \\
5 & $453 \mathrm{~B}$ & 0.707783 & 50.53 \\
2 & 611 & 0.707738 & 50.53 \\
2 & 1087 & 0.707738 & \\
\hline
\end{tabular}

${ }^{\mathrm{a}} \mathrm{The}{ }^{87} \mathrm{Sr} /{ }^{86} \mathrm{Sr}$ ratios are reported for six specimens derived from three Telms. For Telms with multiple measurements, each shell represents a different locality. Error associated with each measurement is calculated using the long-term laboratory standard deviation of NIST 987 as described by Howarth and McArthur [1997]. Using this approach, values reported above have an error of \pm 0.000022 . Replicate analyses are reported for a single shell in Telm 7, which are the same, within analytical error. In some cases, there were multiple solutions for age assignments; the appropriate age was selected (shown here) using the principle of superposition and dinocyst biostratigraphy [Wrenn and Hart, 1988].

using the standard deviation of NIST 987 over an 8 month period $(2 \sigma=0.000022)$. This analytical error was combined with uncertainty in the LOWESS fit to the secular ${ }^{87} \mathrm{Sr} /{ }^{86} \mathrm{Sr}$ curve for marine waters [Howarth and McArthur, 1997] at a 95\% confidence level to yield the total uncertainty in age (Figure 5). The ${ }^{87} \mathrm{Sr} /{ }^{86} \mathrm{Sr}$ values for six specimens from Telms 2, 5, and 7 were used to make age assignments with respect to the timescale of Berggren et al. [1995] (Table 3). Results from samples exhibiting unusual trace element composition indicative of diagenetic alteration (see discussion above) were rejected.

\section{Age Model}

[24] Strontium isotope analyses were performed on Cucullaea specimens to provide a temporal framework for the stable isotope data and to constrain the age of the uppermost portion of the section, in particular. Because the marine $\mathrm{Sr}$ isotope curve oscillates during the Eocene, there was no unique numeric age solution for several of the specimens. In these instances, ages were assigned using the principle of superposition in combination with dinocyst biostratigraphy [Wrenn and Hart, 1988].

[25] When evaluated relative to the ${ }^{87} \mathrm{Sr} /{ }^{86} \mathrm{Sr}$ secular variation curve for marine waters during the Eocene [Howarth and McArthur, 1997], isotopic compositions of samples from Telms 2, 5, and 7 are consistent with marine values and confirm an Eocene age for the La Meseta Formation (Figure 5). Porębski [2000] speculated that the hiatus between Telms 3 and 4 represents the $49.5 \mathrm{Ma}$ eustatic sea level fall, which is also consistent with these age

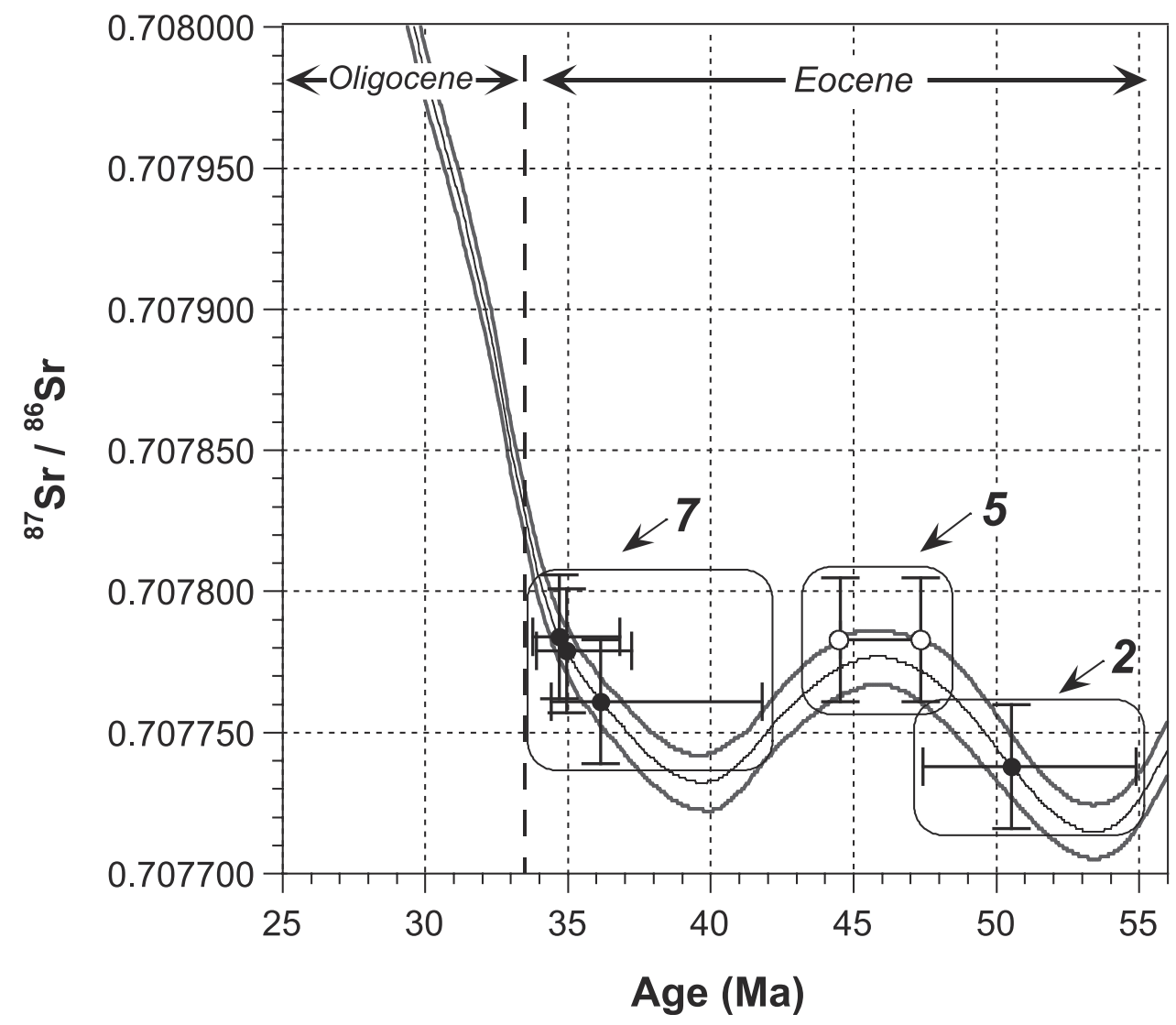

Figure 5. The ${ }^{87} \mathrm{Sr} /{ }^{86} \mathrm{Sr}$ compositions of six Cucullaea shells from the La Meseta Formation plotted on the secular $\mathrm{Sr}$ isotope curve for marine water (solid line) shown with $95 \%$ confidence interval (shaded lines) [Howarth and McArthur, 1997]. Open circles denote multiple possible age assignments for a single shell. Both shells from Telm 2 have identical compositions and therefore appear as a single point. The ${ }^{87} \mathrm{Sr} /{ }^{86} \mathrm{Sr}$ values of Cucullaea shells are comparable with Eocene seawater composition. Most notably, these age assignments indicate a late Eocene age for the uppermost strata of the La Meseta Formation. 
assignments. Most notably, measured ${ }^{87} \mathrm{Sr} /{ }^{86} \mathrm{Sr}$ values are not compatible with an Oligocene age, which would require ${ }^{87} \mathrm{Sr} /{ }^{86} \mathrm{Sr}$ values $\geq 0.707817$.

\section{Paleoenvironmental Reconstruction}

[26] The $\delta^{18} \mathrm{O}$ values of bivalve aragonite simultaneously record temperature and $\delta^{18} \mathrm{O}_{\mathrm{SW}}$. The $\delta^{18} \mathrm{O}_{\mathrm{SW}}$ is influenced by variable salinity and/or continental ice volume due to the sequestering of ${ }^{16} \mathrm{O}$ in the ice. Because meteoric water has lower $\delta^{18} \mathrm{O}$ values than seawater, paleotemperature estimates for coastal settings at middle to high latitudes may be biased toward warmer temperatures if low salinities prevail [Klein and Fricke, 1997]. In addition, formation of small, ephemeral ice sheets in the late Eocene has been postulated through several lines of evidence, including presence of glaciomarine sediment [Wise et al., 1991], ice-rafted debris [Margolis and Kennett, 1971], and very positive $\delta^{18} \mathrm{O}$ values for benthic foraminifers [Zachos et al., 1994]. Owing to the probability that some variation recorded in the oxygen isotope composition of macrofossils at Seymour Island during the Eocene reflects variable $\delta^{18} \mathrm{O}_{\mathrm{SW}}$, it is important to separate the relative contributions of temperature and $\delta^{18} \mathrm{O}_{\mathrm{SW}}$ to the resultant shell composition.

\section{1. $\mathrm{Sr} / \mathrm{Ca}$ Paleothermometry}

[27] To evaluate the extent of temperature effect versus variable seawater $\delta^{18} \mathrm{O}$, we turn to the possibility of extracting temperature from $\delta^{18} \mathrm{O}$ data through paired analysis of an independent elemental paleothermometer. Calibration experiments have demonstrated that $\mathrm{Mg} / \mathrm{Ca}$ ratios in foraminiferal calcite reflect ambient water temperature [Nürnberg et al., 1996; Rosenthal et al., 1997]. Similarly, for biogenic aragonite, $\mathrm{Sr} / \mathrm{Ca}$ ratios have been used as a proxy for temperature in corals [Weber, 1973; Shen et al., 1996], and $\mathrm{Sr} / \mathrm{Ca}$ and temperature have been observed to correlate in several aragonite bivalves [Dodd, 1965; Palacios et al., 1994; Thorn et al., 1995; Klein, 1996].

[28] Ideally, evaluation of minor element paleothermometers for bivalve carbonate should be made through calibration with modern specimens of extant species in either a laboratory or natural setting. Unfortunately, this approach is not feasible for species now extinct, such as $C$. raea and $C$. donaldi. Therefore the approach we have taken is to compare stable isotope and minor element composition from splits of powdered carbonate samples. Correlation between the $\mathrm{Sr} / \mathrm{Ca}$ ratio and $\delta^{18} \mathrm{O}$ would argue for a temperature-controlling mechanism of $\mathrm{Sr}$ content where scatter in this relation may result from variable salinity and/or ice volume effects. Bulk samples drilled from the umbo of the shell do in fact show correlation between $\mathrm{Sr} / \mathrm{Ca}$ and $\delta^{18} \mathrm{O}$, suggesting the possibility that $\mathrm{Sr} / \mathrm{Ca}$ reflects temperature.

[29] We then tested the observed relation between $\delta^{18} \mathrm{O}$ and $\mathrm{Sr} / \mathrm{Ca}$ in Cucullaea by measuring these two parameters along a high-resolution transect of the outer, prismatic layer of shell 453 from Telm 5 (Figure 4). Although there are some similarities between the $\mathrm{Sr} / \mathrm{Ca}$ and $\delta^{18} \mathrm{O}$ profiles of this shell, the relation observed in the bulk samples was not reproduced. The similarity between $\mathrm{Sr} / \mathrm{Ca}$ and $\delta^{13} \mathrm{C}$ in this shell is much stronger and suggests that growth rate may be controlling the incorporation of $\mathrm{Sr}$ into the shell.

[30] Because the purported correlation between $\mathrm{Sr} / \mathrm{Ca}$ and $\delta^{18} \mathrm{O}$ is not substantiated by the high-resolution data, we do not have confidence in the potential for $\mathrm{Sr} / \mathrm{Ca}$ in Cucullaea as an independent paleothermometer. It is interesting to note that highresolution samples were derived near the ventral margin while bulk samples were taken near the umbo of the shell. Consequently, discrepancy between the $\mathrm{Sr} / \mathrm{Ca}-\delta^{18} \mathrm{O}$ relation for these two types of samples could be attributed to ontogenetic differences in the incorporation of Sr. These observations highlight the importance of characterizing the ontogenetic variation in minor element ratios of bivalve carbonate to validate hypotheses based on data from bulk samples.

\subsection{Bivalve Stable Isotope Record}

4.2.1. High-resolution profiles of $\delta^{18} \mathrm{O}$ and $\delta^{13} \mathrm{C}$. [31] Seasonal variability in temperature is not easily documented for ancient climates because few proxies for seasonality exist. Fortunately, accretionary growth structures in bivalve shells allow for documentation of intra-annual and interannual records of temperature variation using $\delta^{18} \mathrm{O}$ [Jones et al., 1983; Dettman et al., 1999]. Many bivalves analyzed elsewhere exhibit annual periodicity in growth bands [Lutz and Rhoads, 1980]. However, annual growth bands have been observed to form during the winter in some instances and during the summer in other cases [Rhoads and Lutz, 1980; Jones and Quitmyer, 1996]. Dark, organic-rich growth bands are most likely formed as a result of growth cessation or slow rates of shell accretion. Possible explanations for growth cessation include thermally controlled shut down [Dettman et al., 1999; Neumann et al., 1993; Weidman et al., 1994; Peck and Conway, 2000], nutrient limitation [Dextraze and Zinsmeister, 1987], or seasonal biorhythms such as spawning [Jones et al., 1983; Weidman, 1995].

[32] Because C. donaldi and C. raea are both extinct species, direct observation of the timing of growth bands is not possible, but indirect evidence via $\delta^{18} \mathrm{O}$ profiles can help to elucidate this aspect of shell growth. In some specimens, dark growth bands appear to consistently coincide with $\delta^{18} \mathrm{O}$ minima (e.g., shell 453), suggesting an interruption in growth during the summer season (Figure 3). However, this pattern does not hold for all growth bands in the other specimens. In some specimens, growth bands appear to correlate with $\delta^{18} \mathrm{O}$ maxima, implying a winter shut down (e.g., shell 6). Irregular patterns observed between extreme values of $\delta^{18} \mathrm{O}$ and growth cessations are most likely a product of multiple processes such as spawning or very low salinity in the summer and nutrient limitation during the winter months in addition to thermally induced growth cessations. We suspect that nutrient limitation was a significant factor in this case because light patterns at high latitudes exert significant control on seasonal growth of phytoplankton and, consequently, on shell growth for filter-feeding bivalves such as Cucullaea. Rates of shell secretion are likely seasonally biased; average shell $\delta^{18} \mathrm{O}$ and consequent paleotemperature estimates may therefore also be seasonally biased. Yet this is not unlike SST estimates based on foraminifer $\delta^{18} \mathrm{O}$, which are likely also biased toward times when active shell secretion is occurring. Although stable isotope profiles of Cucullaea shells are probably truncated due to episodic growth cessations, they still provide minimum estimates for the full seasonal range of $\delta^{18} \mathrm{O}$ and $\delta^{13} \mathrm{C}$.

4.2.2. Seasonality of $\delta^{18} O$. [33] Annual variability observed in high-resolution records of $\delta^{18} \mathrm{O}$ can be influenced by fluctuation in temperature and/or seasonal runoff input that affects salinity. The $\delta^{18} \mathrm{O}$ of freshwater runoff in this region during the Eocene should have been significantly more negative than marine values, owing in part to the high latitudinal position of Seymour Island. Moreover, the presence of large wood fragments [Francis, 1991] as well as plant macrofossils [Case, 1988] suggest that the Antarctic Peninsula was heavily vegetated during deposition of the La Meseta Formation. Such vegetation would contribute a negative carbon isotopic signature to any freshwater runoff. Consequently, if ambient seawater during shell growth of Cucullaea was affected by substantial incursion of freshwater, a mixing trend between the marine and freshwater end-members showing positive correlation should manifest on a plot of $\delta^{13} \mathrm{C}$ versus $\delta^{18} \mathrm{O}$.

[34] Lack of positive covariance between bulk $\delta^{13} \mathrm{C}$ and $\delta^{18} \mathrm{O}$ values of Cucullaea shells (Figure 6) indicates that the stratigraphic 


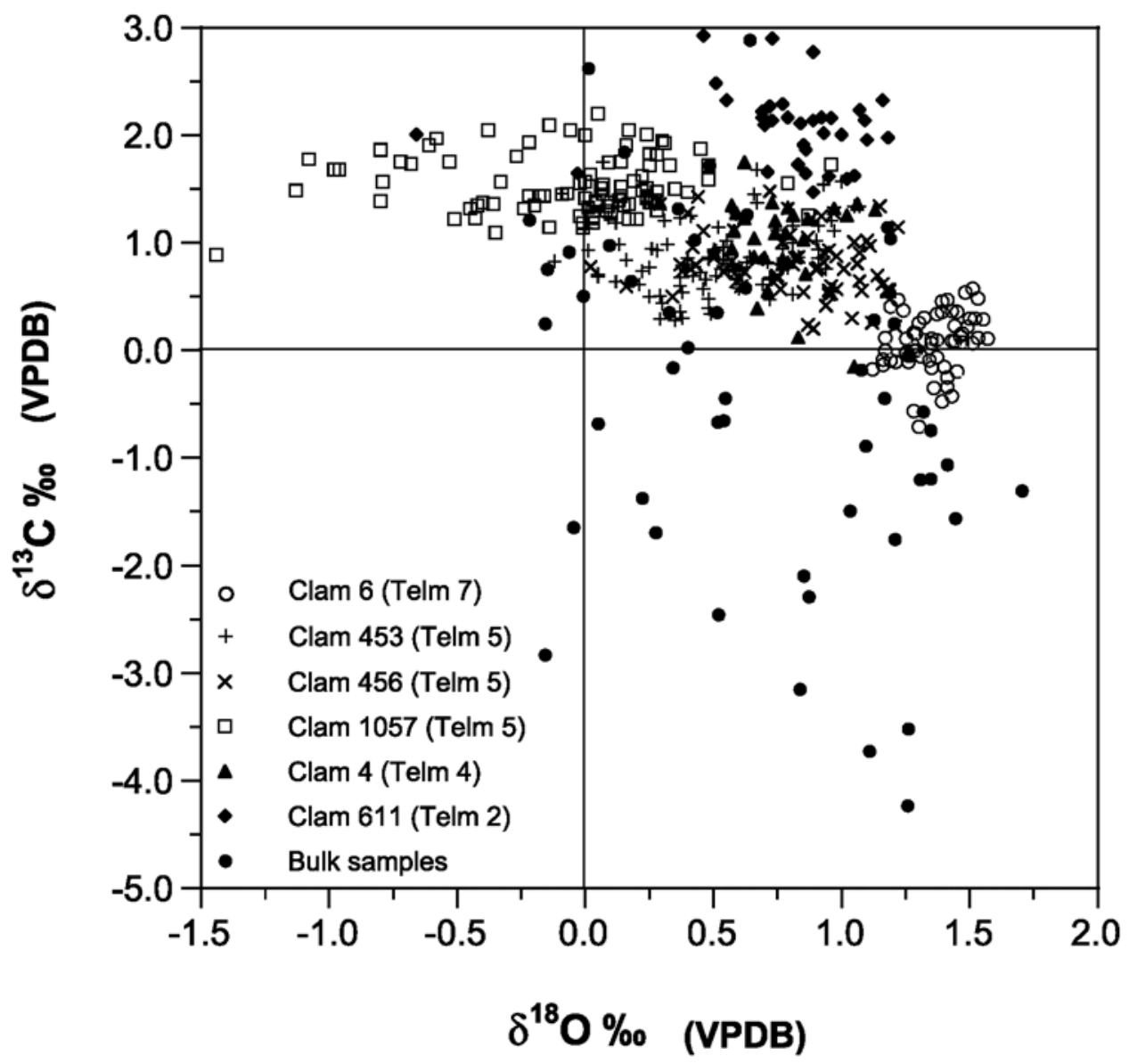

Figure 6. Plot of $\delta^{13} \mathrm{C}$ versus $\delta^{18} \mathrm{O}$ of bulk and high-resolution samples of Cucullaea aragonite from the La Meseta Formation, consistent with a fully marine environment. In contrast, mixing of isotopically light freshwater with marine water would manifest as a mixing line between the two end-member compositions showing positive covariance between $\delta^{13} \mathrm{C}$ and $\delta^{18} \mathrm{O}$.

trend in $\delta^{18} \mathrm{O}$ and $\delta^{13} \mathrm{C}$ (Figure 2) is not a product of local fluctuation in salinity. Moreover, high-resolution samples derived from individual shells plot in a tight cluster for all shells except shell 1057 from Telm 5. The range in $\delta^{13} \mathrm{C}$ for this particular shell is not notably different than the other shells, yet the range of $\delta^{18} \mathrm{O}$ is much larger than the other two shells from Telm 5 (Table 2), causing the data to plot in a roughly horizontal line in Figure 6. In addition, shell 1057 has a lower average $\delta^{18} \mathrm{O}$ than the other shells in Telm 5 (Table 2) as well as occasional synchronous negative excursions in both $\delta^{18} \mathrm{O}$ and $\delta^{13} \mathrm{C}$ (Figure 3). All of these features suggest that the locality where this specimen lived may have been a lower salinity environment, which experienced seasonal incursions of isotopically light freshwater. However, the clustering of stable isotope data for the other shells suggests that seasonally variable salinity is not a significant factor, and we attribute the highresolution $\delta^{18} \mathrm{O}$ record of the remaining five shells solely to fluctuation in temperature.

[35] Amplitude of temperature variation estimated from $\delta^{18} \mathrm{O}$ is larger during intervals characterized by higher mean annual temperature (Telms 2-5) than the amplitude observed in association with the cooler climate of Telm 7 (Table 2). We calculate a total range in temperature of $\sim 4^{\circ}-9^{\circ} \mathrm{C}$ in the early and middle Eocene compared to $2.5^{\circ}$ in the late Eocene. Reduced temperature seasonality (cooler summers) in the latest Eocene was probably a prerequisite to significant ice accumulation, which is observed at the Eocene-Oligocene boundary.
[36] All bivalves sampled from Telms 2 through 5 record maximum $\delta^{18} \mathrm{O}$ values between 1.0 and $1.2 \%$. In contrast, the shell from Telm 7 records a maximum $\delta^{18} \mathrm{O}$ value of $1.6 \%$ (Figure 3 ). The cause of potential growth cessation in Cucullaea ultimately affects the interpretation of this result. For example, if growth ceases below a fixed temperature, then variable $\delta^{18} \mathrm{O}$ at this shutdown point is a reflection of change in $\delta^{18} \mathrm{O}_{\mathrm{SW}}$ due to either a salinity or ice volume effect. Alternatively, if growth cessation (and/or initiation) is triggered by a seasonal signal (e.g., light limitation near the poles can strongly affect phytoplankton production), then this would change the interpretation of $\delta^{18} \mathrm{O}$ profiles. In this case, differences in $\delta^{18} \mathrm{O}$ maxima provide temperature information at a certain time of year and the aforementioned offset in ${ }^{18} \mathrm{O}$ maxima between Telm 7 and Telms $2-5$ would suggest colder winters in the uppermost portion of the La Meseta Formation. Unfortunately, incomplete knowledge of causes for growth cessation in Cucullaea precludes us from making definitive interpretation of the shift in $\delta^{18} \mathrm{O}$ maxima recorded in these highresolution profiles.

4.2.3. The $\delta^{13} \mathrm{C}$ profiles. [37] As mentioned previously, bivalve $\delta^{13} \mathrm{C}$ is not always a faithful recorder of seawater $\delta^{13} \mathrm{C}$ because of variable contributions from metabolic carbon; therefore conclusions with respect to this record must be made with caution. Cucullaea shells exhibit seasonal $\delta^{13} \mathrm{C}$ variation that spans $1.3-1.9 \%$ and display $\delta^{13} \mathrm{C}$ maxima that often coincide with visible growth lines (Figure 3 ). The $\delta^{13} \mathrm{C}$ of surface seawater is 
Table 4. Compilation of Climate Proxy Data Derived From the La Meseta Fossil Record ${ }^{\mathrm{a}}$

\begin{tabular}{lll}
\hline \multicolumn{1}{c}{ Proxy } & \multicolumn{1}{c}{ Climate } & \multicolumn{1}{c}{ Source } \\
\hline Nothofagus fossil wood & cool temperate & Case [1988] \\
Leaf flor & $10^{\circ}-15^{\circ} \mathrm{C}$ & Doktor et al. [1996] \\
Brachiopod faun & $10^{\circ}-14^{\circ} \mathrm{C}$ & Weidman et al. $[1988]$ \\
Molluscan faun & cool or warm temperate & Stilwell and Zinsmeister [1992] \\
$\delta^{18} \mathrm{O}$ of high-Mg calcite cements in & $5.1^{\circ}-13.2^{\circ} \mathrm{C}$ & Pirrie et al. $[1998]$ \\
$\quad$ Teredolites-bored wood & $5.9^{\circ}-12.8^{\circ} \mathrm{C}$ & Ditchfield et al. $[1994]$ \\
$\delta^{18} \mathrm{O}$ of bivalves, oysters, nautiloid & $2.0^{\circ}-13.5^{\circ} \mathrm{C}$ & Gazdzicki et al. $[1992]$ \\
$\delta^{18} \mathrm{O}$ of brachiopods, gastropods, bivalves & $8.0^{\circ}-17.0^{\circ} \mathrm{C}$ & this study \\
$\delta^{18} \mathrm{O}$ of Cucullaea bivalves &
\end{tabular}

${ }^{\mathrm{a}}$ All $\delta^{18} \mathrm{O}$ data have been normalized by setting $\delta^{18} \mathrm{OSW}=-1.0 \%$ and using the paleotemperature equations of O'Neil et al. [1969] for skeletal calcite and Grossman and Ku [1986] for molluscan aragonite. These data represent temperature estimates for the formation as a whole with the exception of the cement data, which are derived from Telms 2 and 3.

strongly influenced by primary productivity owing to the preferential uptake of ${ }^{12} \mathrm{C}$ by planktonic organisms. In this way, seasonal $\delta^{13} \mathrm{C}$ maxima recorded in bivalve carbonate may correspond to times of high productivity when surface waters become depleted in ${ }^{12} \mathrm{C}$. Owing to light limitation at high latitudes we would expect a strong fluctuation in the phytoplankton population on an annual timescale causing variation in seawater $\delta^{13} \mathrm{C}$. In several Cucullaea shells the $\delta^{13} \mathrm{C}$ profile exhibits strong seasonal variation (e.g., shell 453), which could be attributed to seasonal changes in phytoplankton production (Figure 3). Alternatively, $\delta^{13} \mathrm{C}$ may be fluctuating in response to variable incorporation of light metabolic $\mathrm{CO}_{2}$. In this case, lower $\delta^{13} \mathrm{C}$ between the growth bands would suggest increased utilization of metabolic carbon while the organism is actively secreting carbonate shell.

4.2.4. Secular trend in $\delta^{18} \mathbf{O}$. [38] Paleontological studies of floral and faunal assemblages of the La Meseta Formation have provided several important clues to the climate (Table 4). Estimates of paleotemperatures based on skeletal carbonate $\delta^{18} \mathrm{O}$ have also been published for the La Meseta Formation by Gaździcki et al. [1992] and Ditchfield et al. [1994]. Assuming ice-free conditions $\left(\delta^{18} \mathrm{O}_{\mathrm{SW}}=-1.0 \%\right)$, paleotemperatures calculated from these data range from $2.0^{\circ}$ to $13.5^{\circ} \mathrm{C}$ and $5.9^{\circ}$ to $12.8^{\circ} \mathrm{C}$, respectively (Table 4). However, combination of $\delta^{18} \mathrm{O}$ data derived from multiple taxa in these studies makes it difficult to interpret the resultant isotope record uniquely in terms of either absolute value or magnitude of change. Differing ecologies of each taxon and the possibility of resulting vital effect offsets can produce significant isotopic variation within each stratigraphic horizon. Furthermore, apparent shifts in temperature between horizons from which different assemblages of taxa are analyzed may only reflect differences related to taxon-specific vital effects and may not be reflective of changes in SST. Although our analyses include two different species, $C$. raea and $C$. donaldi, we do not have reason to suspect any vital effect offset for $\delta^{18} \mathrm{O}$ values at the species level in bivalves. Modern bivalves have been shown to precipitate their shells in isotopic equilibrium with ambient fluids with respect to oxygen [Epstein et al., 1953; Jones et al., 1983; Israelson et al., 1994; Weidman et al., 1994; Hickson et al., 1999], although they may show offsets for carbon [Tanaka et al., 1986; Krantz et al., 1987; Dettman et al., 1999].

[39] The $\delta^{18} \mathrm{O}$ values of bulk samples from Cucullaea shells from Telms 2-7 yield SSTs ranging from $8.0^{\circ}$ to $17.0^{\circ} \mathrm{C}$. This broad range is in general agreement with most of the aforementioned independent proxies of temperature but encompasses slightly warmer temperatures than previously published $\delta^{18} \mathrm{O}$ data for the Eocene La Meseta Formation. Average temperatures for each Telm range from $10.5^{\circ}$ to $15.5^{\circ} \mathrm{C}$ (Table 1 ), which is nearly identical to the range predicted on the basis of faunal and floral assemblages (Table 4). The range and standard deviation in $\delta^{18} \mathrm{O}$ differs greatly from Telm to Telm (Table 1). However, each pool of specimens derived from multiple localities within a Telm undoubtedly represents a substantial yet unknown amount of time averaging. Consequently, apparent scatter in bivalve isotope composition within a single Telm may be a result of a temporal trend that has been collapsed through time averaging. For example, Telm 5 has the largest range in bulk isotope composition, but it is also the thickest Telm in the section. Unfortunately, the lack of internal stratigraphy for localities within a Telm prevents us from being able to resolve trends in $\delta^{18} \mathrm{O}$ at higher stratigraphic resolution.

[40] The temporal pattern of observed $\delta^{18} \mathrm{O}$ values for Cucullaea parallels the trend of foraminiferal $\delta^{18} \mathrm{O}$ generated from high southern latitude Deep Sea Drilling Program (DSDP) and Ocean Drilling Program (ODP) sites, which is characterized by a pattern of increasing $\delta^{18} \mathrm{O}$ from late early to late Eocene [Shackleton and Kennett, 1975; Stott et al., 1990]. For comparison, the $\delta^{18} \mathrm{O}$ trend for Cucullaea shells from Seymour Island has been plotted with planktonic foraminiferal records from Maud Rise, located at $65^{\circ} \mathrm{S}$ in the Weddell Sea, Antarctica (Figure 7). Maud Rise is located at almost the same latitudinal position as Seymour Island but is $\sim 700$ $\mathrm{km}$ north of the Antarctic continent where modern water depth is $2000-3000 \mathrm{~m}$. The similarity of results from Seymour Island and Maud Rise suggests that fossil molluscan and foraminifer records preserved on Seymour Island are faithful recorders of regional paleoclimatic signals rather than strictly local conditions.

[41] The $\delta^{18} \mathrm{O}$ of Cucullaea aragonite appears to track the upper limit of temperatures calculated from $\delta^{18} \mathrm{O}$ of mixed layer dwelling planktonic foraminifers at Maud Rise (Figure 7). The population of Cucullaea shells in each Telm may represent a spectrum of environments, from fully marine to mixed marine and freshwater. However, because our data overlap with the warmest of the planktonic foraminifers at this site, it would be difficult to argue that our $\delta^{18} \mathrm{O}$ data are substantially affected by low salinities. For Telms that are well constrained in age by ${ }^{87} \mathrm{Sr} /{ }^{86} \mathrm{Sr}$ stratigraphy the average $\delta^{18} \mathrm{O}$ is consistently $\sim 1.25 \%$ lighter than the subthermocline foraminifers at Maud Rise (Figure 7). Stott et al. [1990] noted that the offset between Acaranina and Subbotina (surface and subthermocline dwelling foraminifers) was also maintained at $\sim 1.25 \%$ o throughout the early and middle Eocene. Because Acaranina go extinct just before the middle/late Eocene boundary [Stott and Kennett, 1990], the gradient between surface and subthermocline water temperatures in the late Eocene could not be calculated from the Maud Rise data. Using the Cucullaea $\delta^{18} \mathrm{O}$ record, we are able to confirm that this gradient remained the same into the late Eocene.

[42] The most notable feature in the temporal progression of $\delta^{18} \mathrm{O}$ documented here is the shift to more positive values between Telms 5 and 6 (Figure 7). Average $\delta^{18} \mathrm{O}$ increases by $0.8 \%$ between 


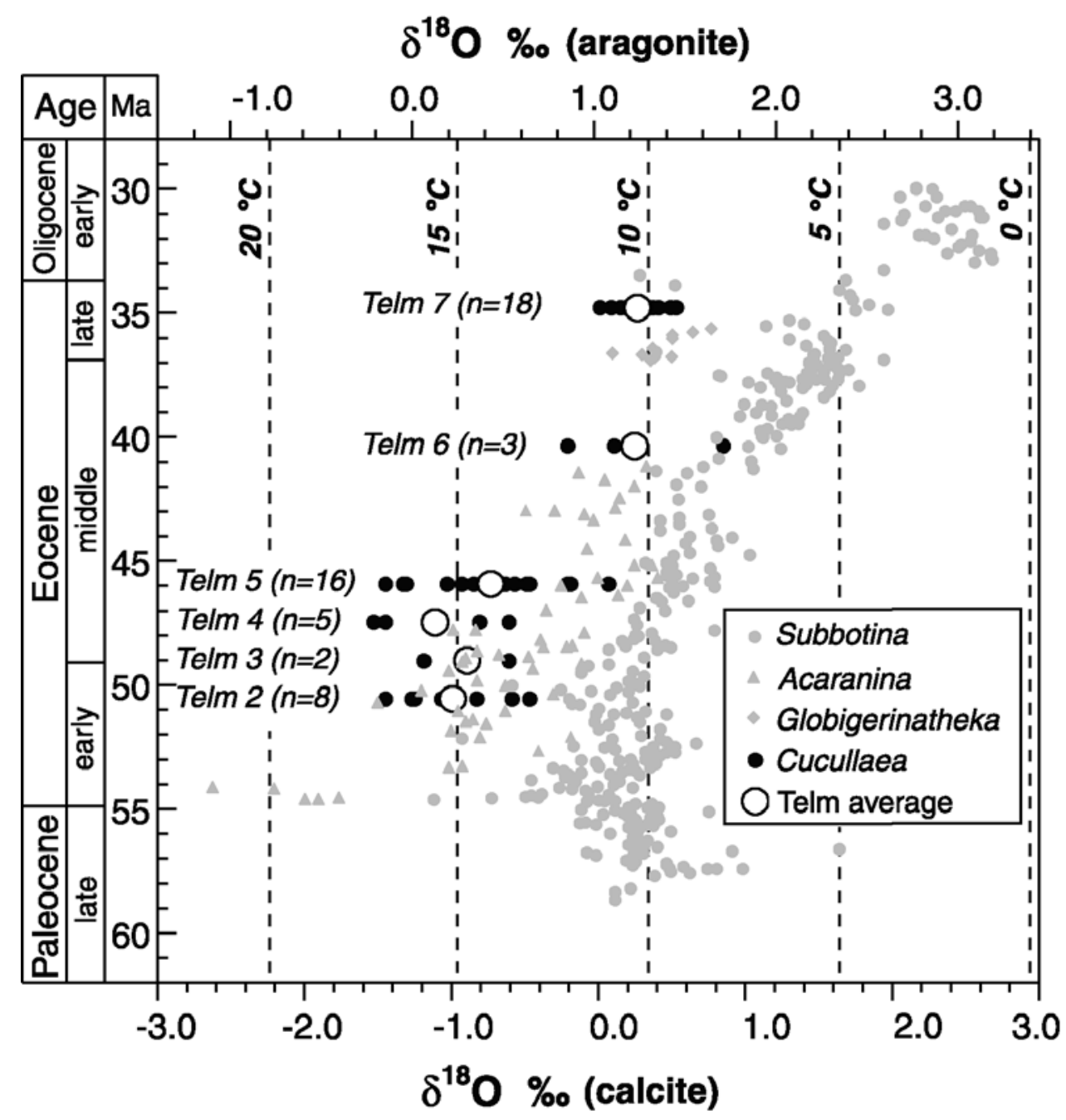

Figure 7. Evolution of Antarctic sea surface temperatures as recorded by planktonic surface-dwelling foraminifers from ODP Sites 689 and 690 on Maud Rise (shaded symbols [Stott et al., 1990]) and Cucullaea from Telms 2-7 of the La Meseta Formation (solid circles). Average $\delta^{18} \mathrm{O}$ composition of Cucullaea is shown for each Telm (open circles). Paleotemperatures are calculated assuming ice-free conditions $\left(\delta^{18} \mathrm{O}_{\mathrm{SW}}=-1.0 \% \mathrm{SMOW}\right)$ using equations of Grossman and Ku [1986] for aragonite Cucullaea shells and Erez and Luz [1983] for calcite foraminifers. Ages for Telms were assigned using ${ }^{87} \mathrm{Sr} /{ }^{86} \mathrm{Sr}$ stratigraphy for Telms 2, 5, and 7; remaining Telms are spaced equally between dated horizons. Species of the genera Acaranina and Globigerinatheka lived in the mixed layer; Subbotina is considered a subthermocline taxon. Note that Cucullaea $\delta^{18} \mathrm{O}$ overlaps with the foraminifers exhibiting the lowest $\delta^{18} \mathrm{O}$ values (warmest temperatures).

Telms 5 and 6, which corresponds to a decrease in temperature of nearly $4^{\circ} \mathrm{C}$, an increase in ice volume equivalent to $80 \%$ of presentday ice volume [Shackleton and Kennett, 1975], or some combination thereof. Note that because this positive shift in $\delta^{18} \mathrm{O}$ spans a hiatus between Telms 5 and 6 , the increase may have been abrupt or gradual. The presence of small, ephemeral ice sheets during the Eocene was proposed by Zachos et al. [1994] on the basis of relatively positive benthic foraminiferal $\delta^{18} \mathrm{O}$ values as well as clay mineral assemblages and ice-rafted debris in ODP cores from Maud Rise and Kerguelen Plateau [Ehrmann and Mackensen, 1992]. Although this scenario is possible, because of the lack of conclusive evidence for large-scale Eocene glaciation in oceanic records [Wise et al., 1992], it is unlikely that the $+0.8 \%$ shift observed in Cucullaea shells is entirely a product of ice accumulation on land. Hence we attribute the majority of this shift to cooling of surface waters during the middle and late Eocene but do not rule out the possibility for some component of ice accumulation.
[43] The positive $\delta^{18} \mathrm{O}$ shift between Telms 5 and 6 is contemporaneous with an angular unconformity [Porebski, 2000], a considerable decrease in diversity of molluscan and brachiopod faunas [Stilwell and Zinsmeister, 1992; Bitner, 1996], and faunal turnover in many of the taxa [Zinsmeister and Camacho, 1982]. The change in character of the faunal assemblage during this transition may be a direct response to cooler surface water temperatures. It is also interesting to note that replacement of the thickshelled, larger $C$. raea with the thinner-shelled and significantly smaller $C$. donaldi also occurs between Telms 5 and 6 , which might reflect diminished length of the growing season due to colder temperatures.

\section{Conclusions}

[44] Measured ${ }^{87} \mathrm{Sr} /{ }^{86} \mathrm{Sr}$ ratios of Cucullaea shells confirm an Eocene age for the La Meseta Formation. The observed trend in 
$\delta^{18} \mathrm{O}$ of Cucullaea aragonite is very similar to both patterns and absolute values observed in high southern latitude foraminiferal $\delta^{18} \mathrm{O}$ records. A prominent positive shift in the $\delta^{18} \mathrm{O}$ record occurs between Telms 5 and 6 , coincident with a decrease in biodiversity and faunal turnover in the La Meseta paleoenvironment. This increase is attributed to cooling of surface waters during the middle and late Eocene but may also reflect some component of ice accumulation. Seasonal profiles of stable isotope compositions reported here provide minimum estimates of annual range in temperature for coastal Antarctica during the Eocene. Cooler climate during deposition of Telms 6 and 7 and just prior to extensive Antarctic glaciation in the earliest Oligocene is associated with a significant decrease in seasonal temperature range preserved in Cucullaea shells.

[45] $\mathrm{Sr} / \mathrm{Ca}$ content in Cucullaea shells does not appear to have potential as an independent paleothermometer for Cucullaea specimens. However, this does not rule out the possibility that minor element ratios in bivalve carbonate in other taxa may be effective proxies for temperature. Future development of such independent proxies for bivalve carbonate will be instrumental for interpreting the relative contributions of temperature, salinity, and ice volume to bivalve $\delta^{18} \mathrm{O}$

[46] Acknowledgments. Support for this research was provided by the National Science Foundation (NSF Graduate Student Fellowship to A. Dutton and NSF OPP grant 9318212 to K. Lohmann and E. Barrera) and the University of Michigan Scott Turner Fund. All geochemical analyses were performed in facilities at the University of Michigan. We are grateful to Lora Wingate, Ted Huston, and Andrea Klaue for providing analytical expertise and to Joel Blum and Don Peacor for use of their laboratories. This manuscript benefited greatly from the careful reviews of Mark Leckie, Ken McLeod, and Birger Schmitz. We also thank Bruce Wilkinson and David Fox for their helpful comments on earlier versions of this manuscript.

\section{References}

Andreasson, F. P., and B. Schmitz, Winter and summer temperatures of the early middle Eocene of France from Turritella $\delta^{18} \mathrm{O}$ profiles, Geology, 24, 1067-1070, 1996

Andreasson, F. P., and B. Schmitz, Tropical Atlantic seasonal dynamics in the early middle Eocene from stable oxygen and carbon isotope profiles of mollusk shells, Paleoceanography, 13, 183-192, 1998.

Andreasson, F. P., and B. Schmitz, Temperature seasonality in the early middle Eocene North Atlantic region: Evidence from stable isotope profiles of marine gastropod shells, Geol. Soc. Am. Bull., 112(4), 628-640, 2000.

Aronson, R. B., D. B. Blake, and T. Oji, Retrograde community structure in the late Eocene of Antarctica, Geology, 25(10), 903-906, 1997.

Askin, R. A., D. H. Elliot, J. D. Stilwell, and W. J. Zinsmeister, Stratigraphy and paleontology of Campanian and Eocene sediments, Cockburn Island, Antarctic Peninsula, J. S. Am. Earth Sci., 4(1/2), 99-117, 1991.

Baumiller, T. K., and A. Gaździcki, New crinoids from the Eocene La Meseta Formation of Seymour Island, Antarctic Peninsula, in Palaeontological Results of the Polish Antarctic Expedition, Part II, edited by A. Gaździcki, Palaeontol. Polonica, 55, 101-116, 1996.

Berggren, W. A., D. V. Kent, C. C. Swisher, and M.-P. Aubry, A revised Cenozoic geochronology and chronostratigraphy, in Geochronology, Time Scales and Global Stratigraphic Correlation, Spec. Publ. SEPM Soc. Sediment. Geol., 54, 129-212, 1995

Bice, K. L., M. A. Arthur, and L. Marincovich, Late Paleocene Arctic Ocean shallow-marine temperatures from mollusc stable isotopes, $\mathrm{Pa}$ leoceanography, 11, 241-249, 1996.

Bice, K. L., E. J. Barron, and W. H. Peterson, Continental runoff and early Eocene bottomwater sources, Geology, 25, 951-954, 1997.

Bitner, M. A., Brachiopods from the Eocene La Meseta Formation of Seymour Island, Antarctic Peninsula, in Palaeontological Results of the Polish Antarctic Expedition, Part II, edited by A. Gaździcki, Palaeontol. Polonica, 55, $65-100,1996$

Blake, D. B., and W. J. Zinsmeister, Eocene asteroids (Echinodermata) from Seymour Island, Antarctic Peninsula, in Geology and Paleontology of Seymour Island, Antarctic Peninsula, edited by R. Feldmann and M. Woodburne, Mem. Geol. Soc. Am., 169, 489-498, 1988.

Broecker, W. S., The salinity contrast between the Atlantic and Pacific Oceans during glacial time, Paleoceanography, 4, 207-212, 1989.
Case, J. A., Paleogene floras from Seymour Is land, Antarctic Peninsula, in Geology and $\mathrm{Pa}$ leontology of Seymour Island, Antarctic Peninsula, edited by R. Feldmann and M. Woodburne, Mem. Geol. Soc. Am., 169 523-530, 1988.

Case, J. A., Evidence from fossil vertebrates for a rich Eocene Antarctic marine environment, in The Antarctic Paleoenvironment: A perspective on global change, Antarct. Res. Ser, vol. 56, pp. 119-130, AGU, Washington, D. C., 1992

Dettman, D. L., and K. C Lohmann, Microsampling carbonates for stable isotope and minor element analysis: Physical separation of samples on a 20 micrometer scale, J. Sediment. Res. Sect. A, 65, 566-569, 1995.

Dettman, D. L., A. K. Reische, and K. C Lohmann, Controls on the stable isotope composition of seasonal growth bands in aragonitic fresh-water bivalves (unionidae), Geochim Cosmochim. Acta , 63, 1049-1057, 1999.

Dextraze, B. L., and W. J. Zinsmeister, A study of the internal annual growth lines of the late Eocene mollusk Eurhomalea Antarctica, Antarct. J. U. S., 22(5), 14-15, 1987.

Ditchfield, P. W., J. D. Marshall, and D. Pirrie, High latitude palaeotemperature variation: New data from the Tithonian to Eocene of James Ross Island, Antarctica, Palaeogeogr. Palaeoclimatol. Palaeoecol., 107, 79-101, 1994

Dodd, J. R., Environmental control of strontium and magnesium in Mytilus, Geochim. Cosmochim. Acta, 29, 385-398, 1965.

Doktor, M., A. Gaździcki, A. Jerzmanska, and S. J. Porebski, A plant-and-fish assemblage from the Eocene La Meseta Formation of Seymour Island (Antarctic Peninsula) and its environmental implications, in Palaeontological Re sults of the Polish Antarctic Expedition, Part II, edited by A. Gaździcki, Palaeontol. Polonica, 55, 127-146, 1996.

Ehrmann, W. U., and A. Mackensen, Sedimentological evidence for the formation of an Eas Antarctic ice sheet in Eocene/Oligocene time, Palaeogeogr. Palaeoclimatol. Palaeoecol., 93 85-112, 1992

Elliot, D. H., Tectonic setting and evolution of the James Ross Basin, northern Antarctic Peninsula, in Geology and Paleontology of Sey mour Island, Antarctic Peninsula, edited by R. Feldmann and M. Woodburne, Mem. Geol. Soc. Am., 169, 541-555, 1988.

Elliot, D. H., and T. A. Trautman, Lower Tertiary strata on Seymour Island, Antarctic Peninsula, in Antarctic Geosciences, edited by C. Crad- dock, pp. 287-297, Univ. of Wis. Press, Madison, 1982.

Epstein, S., R. Buchsbaum, H. A. Lowenstam, and H.C. Urey, Revised carbonate-water isotopic temperature scale, Geol. Soc. Am. Bull., 64, 1315-1326, 1953

Erez, B., and J. Luz, Experimental paleotemperature equation for planktonic foraminifera, Geochim. Cosmochim. Acta, 47, 1025-1031, 1983

Fairbanks, R. G., C. D. Charles, and F. D. Wright, Origin of global meltwater pulses, in Radiocarbon After Four Decades: An Interdisciplinary Perspective, edited by $\mathrm{R}$. Taylor et al., pp. 473-500, Springer-Verlag, New York, 1992.

Feldmann, R. M., and M. T. Wilson, Eocene decapod crustaceans from Antarctica, in Geology and Paleontology of Seymour Island, Antarctic Peninsula, edited by R. Feldmann and M. Woodburne, Mem. Geol. Soc. Am., 169 465-488, 1988 .

Filkhorn, H. F., Fossil Scleractinian corals from James Ross Basin, Antarctica, Antarct. Res. Ser., 65, 96 pp., AGU, Washington, D.C., 1994

Francis, J. E., Palaeoclimatic significance of Cretaceous-early Tertiary fossil forests of the Antarctic Peninsula, in Geological Evolution of Antarctica, edited by M. Thomson et al., pp. 623-627, Cambridge Univ. Press, New York, 1991

Gaździcki, A., M. Gruszczynski, A. Hoffman, K. Malkowski, S. A. Marenssi, S. Halas, and A. Tatur, Stable carbon and oxygen isotope record in the Paleogene La Meseta Formation, Seymour Island, Antarctica, Antarct. Sci., 4(4), 461-468, 1992.

Greenwood, D. R., and S. L. Wing, Eocene continental climates and latitudinal temperature gradients, Geology, 23(11), 1044-1048, 1995.

Grossman, E. L., and T.-L. Ku, Oxygen and carbon isotope fractionation in biogenic aragonite: Temperature effects, Chem. Geol., 59, 59-74, 1986.

Hall, S. A., Cretaceous and Tertiary dinoflagellates from Seymour Island, Antarctica, Nature, 267, 239-241, 1977.

Hickson, J. A., A. L. A. Johnson, T. H. E. Heaton, and P. S. Balson, The shell of the Queen Scallop Aequipecten opercularis (L.) as a promisiong tool for palaeoenvironmental reconstruction: Evidence and reasons for equilibrium stable-isotope incorporation, Palaeogeogr. Palaeoclimatol. Palaeoecol., 154 325-337, 1999.

Howarth, R. J., and J. M. McArthur, Statistics for 
strontium isotope stratigraphy: A robust LOWESS fit to the marine Sr-isotope curve for 0 to $206 \mathrm{Ma}$, with look-up table for derivation of numeric age, J. Geol., 105, 441-456, 1997.

Huber, B. T., D. A. Hodell, and C. P. Hamilton, Middle-late Cretaceous climate of the southern high latitudes: Stable isotopic evidence for minimal equator-to-pole thermal gradients, Geol. Soc. Am. Bull., 107(10), 1164-1191, 1995.

Israelson, C., B. Buchardt, S. Funder, and H. W. Hubberten, Oxygen and carbon isotope composition of Quaternary bivalve shells as a water mass indicator: Last interglacial and Holocene, east Greenland, Palaeogeogr. Palaeoclimatol. Palaeoecol., 111, 119-134, 1994.

Jones, D. S., and I. R. Quitmyer, Marking time with bivalve shells: Oxygen isotopes and season of annual increment formation, Palaios, 11, 340-346, 1996

Jones, D. S., D. F. Williams, and M. A. Arthur, Growth history and ecology of the Atlantic surf clam, Spisula solidissima (Dillwyn), as revealed by stable isotopes and annual shell increments, J. Exp. Mar. Biol. Ecol., 73, 225-242, 1983

Klein, R. T., A study of biological and physical controls on the stable isotope and trace metal content of biogenic and inorganic calcium carbonate, Ph.D. thesis, 234 pp., Univ. of Mich., Ann Arbor, 1996.

Klein, R. T., and H. C. Fricke, Winter and summer temperature of the early middle Eocene of France from Turitella $\delta^{18} \mathrm{O}$ profiles: Comments and Reply, Geology, 25(10), 957-958, 1997.

Krantz, D. E., D. F. Williams, and D. S. Jones, Ecological and paleoenvironmental information using stable isotope profiles from living and fossil molluscs, Palaeogeogr. Palaeoclimatol. Palaeoecol., 58, 249-266, 1987.

Lutz, R. A., and D. C. Rhoads, Growth patterns within the molluscan shell; an overview, in Skeletal Growth of Aquatic Organisms: Biological Records of Environmental Change, edited by D. Rhoads and R. Lutz, pp. 203-254, Plenum, New York, 1980.

Mackensen, A., and W. U. Ehrmann, Middle Eocene through early Oligocene climate history and paleoceanography in the Southern Ocean: Stable oxygen and carbon isotopes from ODP Sites on Maud Rise and Kerguelen Plateau, Mar. Geol., 108, 1-27, 1992.

Margolis, S., and J. P. Kennett, Cenozoic paleoglacial history of Antarctica recorded in Subantarctic deep-sea cores, Am. J. Sci., 271(1), $1-36,1971$.

McKinney, M. L., K. J. McNamara, and L. A. Wiedman, Echinoids from the La Meseta Formation (Eocene), Seymour Island, Antarctica, in Geology and Paleontology of Seymour Island, Antarctic Peninsula, edited by R. Feldmann and M. Woodburne, Mem. Geol. Soc. Am., 169, 499-503, 1988.

Neumann, D., J. Borcherding, and B. Jantz, Growth and seasonal reproduction of Dreissena polymorpha in the Rhine River and adjacent waters, in Zebra Mussels: Biology, Impacts, and Control, edited by T. Nalepa and D. Schloesser, pp. 95-110, A. F. Lewis, New York, 1993.

Norton, I. O., and J. C. Sclater, A model for the breakup of Gondwanaland, J. Geophys. Res., 84, 6803-6830, 1979.

Nürnberg, D., J. Bijma, and C. Hemleben, Assessing the reliability of magnesium in foraminiferal calcite as a proxy for water mass temperatures, Geochim. Cosmochim. Acta, 60(5), 803-814, 1996.
O’Neil, J. R., R. N. Clayton, and T. K. Mayeda, Oxygen isotope fractionation in divalent metal carbonates, J. Chem. Phys., 51(12), $5547-$ $5558,1969$.

Palacios, R., J. M. Orensanz, and D. A. Armstrong, Seasonal and life-long variation of $\mathrm{Sr} /$ Ca ratio in shells of Mya arenaria from Grays Harbor (Washington) - An ancillary criterion in demographic studies, Estuarine Coastal Shelf Sci., 39, 313-327, 1994.

Peck, L. S., and L. Z. Conway, The myth of metabolic cold adaptation: Oxygen consumption in stenothermal Antarctic bivalves, in The Evolutionary Biology of the Bivalvia, edited by Harper et al., Geol. Soc. Spec. Publ., 177, 441-450, 2000.

Pirrie, D., J. D. Marshall, and J. A. Crame, Marine high $\mathrm{Mg}$ calcite cements in Teredolitesbored fossil wood; Evidence for cool paleoclimates in the Eocene La Meseta Formation, Seymour Island, Antarctica, Palaios, 13, 276-286, 1998.

Porębski, S. J., Facies architecture in a tectonically-controlled incised-valley estuary: La Meseta Formation (Eocene) of Seymour Island, Antarctic Peninsula, Stud. Geol. Polonica, 107, 7-97, 1995.

Porębski, S. J., Shelf-valley compound fill produced by fault subsidence and eustatic sea-level changes, Eocene La Meseta Formation, Seymour Island, Antarctica, Geology, 28(2), 147-150, 2000.

Price, G. D., B. W. Sellwood, and D. Pirrie, Middle-late Cretaceous climate of the southern high latitudes: Stable isotopic evidence for minimal equator-to-pole thermal gradients: Discussion and reply, Geol. Soc. Am. Bull., 108(9), 1192-1196, 1996.

Purton, L., and M. Braiser, Gastropod carbonate $\delta^{18} \mathrm{O}$ and $\delta^{13} \mathrm{C}$ values record strong seasonal productivity and stratification shifts during the late Eocene in England, Geology, 25(10), 871-874, 1997.

Purton, L. M. A., G. A. Shields, M. D. Brasier, and G. W. Grime, Metabolism controls $\mathrm{Sr} / \mathrm{Ca}$ ratios in fossil aragonitic mollusks, Geology, 27(12), 1083-1086, 1999.

Rhoads, D. C., and R. A. Lutz (Eds.), Skeletal Growth of Aquatic Organisms: Biological Records of Environmental Change, 750 pp., Plenum, New York, 1980.

Rosenthal, Y., E. A. Boyle, and N. Slowey, Temperature control on the incorporation of magnesium, strontium, fluorine, and cadmium into benthic foraminiferal shells from Little Bahama Bank: Prospects for thermocline paleoceanography, Geochim. Cosmochim. Acta, 61, 3633-3643, 1997.

Sadler, P. M., Geometry and stratification of uppermost Cretaceous and Paleogene units on Seymour Island, northern Antarctic Peninsula, in Geology and Paleontology of Seymour Island, Antarctic Peninsula, edited by R. Feldmann and M. Woodburne, Mem. Geol. Soc. Am., 169, 303-320, 1988.

Schmitz, B., and F. P. Andreasson, Air humidity and lake $\delta^{18} \mathrm{O}$ during the latest Paleocene-earliest Eocene in France from recent and fossil fresh-water and marine gastropod $\delta^{18} \mathrm{O}, \delta^{13} \mathrm{C}$, and ${ }^{87} \mathrm{Sr} /{ }^{86} \mathrm{Sr}$, Geol. Soc. Am. Bull., 113(6), 774-789, 2001.

Shackleton, N. J., and J. P. Kennett, Paleotemperature history of the Cenozoic and the initiation of Antarctic glaciation: Oxygen and carbon isotope analyses in DSDP Sites 277, 279 and 281, Initial Rep. Deep Sea Drill. Proj., 74, 743-755, 1975 .

Shen, C.-C., T. Lee, C.-Y. Chen, C.-H. Wang,
C.-F. Dai, and L.-A. Li, The calibration of $\mathrm{D}[\mathrm{Sr} / \mathrm{Ca}]$ versus sea surface temperature relationship for Porites corals, Geochim. Cosmochim. Acta, 60, 3849-3858, 1996.

Stilwell, J. D., and W. J. Zinsmeister, Molluscan Systematics and Biostratigraphy: Lower Tertiary La Meseta Formation, Seymour Island, Antarctic Peninsula, Antarct. Res. Ser., vol. 55 , 192 pp., AGU, Washington, D. C., 1992.

Stott, L. D., and J. P. Kennett, Antarctic Paleogene planktonic foraminifer biostratigraphy, ODP Leg 113, sites 689 and 690, Proc. Ocean Drill. Program Sci. Results, 113, 549-569, 1990.

Stott, L. D., J. P. Kennett, N. J. Shackleton, and R. M. Corfield, The evolution of Antarctic surface waters during the Paleogene: Inferences from the stable isotopic composition of planktonic foraminifers, ODP Leg 113, Proc. Ocean Drill. Program Sci. Results, 113, 849-863, 1990.

Tanaka, N., M. C. Monaghand, and D. M. Rye, Contribution of metabolic carbon to mollusc and barnacle shell carbonate, Nature, 320, 520-523, 1986.

Thorn, K., R. M. Cerrato, and M. L. Rivers, Elemental distributions in marine bivalve shells as measured by synchrotron X-ray fluorescence, Biol. Bull., 188, 57-67, 1995.

Weber, J. N., Incorporation of strontium into reef coral skeletal carbonate, Geochim. Cosmochim. Acta, 37, 2173-2190, 1973.

Weidman, C. R., Development and application of the mollusc Arctica islandica as a paleoceanographic tool for the North Atlantic Ocean, Ph.D. thesis, 201 pp., MIT/WHOI Joint Program, Woods Hole, Mass., 1995.

Weidman, C. R., G. A. Jones, and K. C Lohmann, The long-lived mollusc Arctica islandica: A new paleoceanographic tool for the reconstruction of bottom temperatures for the continental shelves of the northern North Atlantic Ocean, $J$. Geophys. Res., 99, 18,305-18,314, 1994.

Weidman, L. A., R. M. Feldmann, D. E. Lee, W. J. Zinsmeister, Brachiopoda from the La Meseta Formation (Eocene) Seymour Island, Antarctica, in Geology and Paleontology of Seymour Island, Antarctic Peninsula, edited by R. Feldmann and M. Woodburne, Mem. GSA, 169, pp. 303-320, GSA, Boulder, 1988.

Welton, B. J., and W. J. Zinsmeister, Eocene neoselachians from the La Meseta Formation, Seymour Island, Antarctic Peninsula, Nat. Hist. Mus. Los Angeles County Contrib. Sci., 329, 1-10, 1980.

Wiman, C., Über die alttertiä;ren vertebraten der Seymour-Insel, Wissensch. Ergebnisse Schwed. Südpolar Exp. 1901-1903, 3(1), 137, 1905.

Wise, S. W., Jr., J. R. Breza, D. M. Harwood, and W. Wei, Paleogene glacial history of Antarcti$\mathrm{ca}$, in Controversies in Modern Geology, pp. 133-171, Academic, San Diego, Calif., 1991. Wise, S. W., Jr., J. R. Breza, D. M. Harwood, W. Wei, and J. C. Zachos, Paleogene glacial history of Antarctica in light of Leg 120 drilling results, Proc. Ocean Drill. Program Sci. Results, 120, 1001-1030, 1992.

Woodburne, M. O., and W. J. Zinsmeister, The first land mammal from Antarctica and its biogeographic implications, J. Paleontol., 58(4), 913-948, 1984.

Wrenn, J. H., and G. F. Hart, Paleogene dinoflagellate cyst biostratigraphy of Seymour Island, Antarctica, in Geology and Paleontology of Seymour Island, Antarctic Peninsula, edited by R. Feldmann and M. Woodburne, Mem. Geol. Soc. Am., 169, 321-447, 1988.

Zachos, J. C., W. A. Berggren, M.-P. Aubry, and 
A. Mackensen, Isotope and trace element geochemistry of Eocene and Oligocene foraminifers from site 748, Kerguelen Plateau, Proc. Ocean Drill. Program Sci. Results, 120 , 937-960, 1992.

Zachos, J. C., L. D. Stott, and K. C Lohmann, Evolution of early Cenozoic marine temperatures, Paleoceanography, 9, 353-387, 1994.

Zachos, J., M. Pagani, L. Sloan, E. Thomas, and K. Billups, Trends, rhythms and aberrations in global climate $65 \mathrm{Ma}$ to present, Science, 292, 686-693, 2001.

Zinsmeister, W. J., Late Eocene bivalves (Mol- lusca) from the La Meseta Formation, collected during the 1974-1975 joint ArgentineAmerican expedition to Seymour Island, Antarctic Peninsula, J. Paleontol., 58(6), $1497-$ $1527,1984$.

Zinsmeister, W. J., and H. H. Camacho, Late Eocene (to possible earliest Oligocene) molluscan fauna of the La Meseta Formation of Seymour Island, Antarctic Peninsula, in Antarctic Geosciences, edited by C. Craddock, pp. 299304, Univ. of Wis. Press, Madison, 1982.

Zinsmeister, W. J., and R. M. Feldmann, Cenozoic high latitude heterochroneity of Southern
Hemisphere marine faunas, Science, 224, 281-283, 1984.

A. L. Dutton and K. C Lohmann, Department of Geological Sciences, University of Michigan, 2534 C. C. Little Building, 425 East University Avenue, Ann Arbor, MI 48109, USA. (adutton@ umich.edu)

W. J. Zinsmeister, Department of Earth and Atmospheric Sciences, Purdue University, West Lafayette, IN 47907, USA. 